\title{
Constructions of Cancer among Survivors in Bandung Society
}

\author{
${ }^{1}$ Amalia Djuwita, ${ }^{2}$ Deddy Mulyana \\ ${ }^{1}$ School of Communications and Business, Telkom University, Indonesia \\ ${ }^{2}$ Faculty of Communication Sciences, Padjadjaran University, Bandung, Indonesia \\ E-mail: 1djuwita@telkomuniversity.ac.id, ${ }^{2}$ deddy.mulyana@unpad.ac.id
}

\begin{abstract}
People assume that cancer is a deadly disease. The communication gap between physicians and their patients results in incomplete information obtained by people with cancer. This research was conducted using a qualitative approach in order to explore the meaning of cancer within Bandung Cancer Society. Theories used as references are phenomenology and symbolic interactionism. The results of the study of 10 informants indicated that cancer is a very frightening disease; cannot be cured and results in no hope of survival; cancer is caused by unhealthy life style; and yet cancer increases acts of worship. All informants as cancer survivors made efforts to survive by following the doctor's advice. Another result of this study states that communication that takes place between cancer survivors and other people with cancer within the Bandung Cancer Society has managed to change the view of cancer, motivate and raise the spirit of life.
\end{abstract}

Keywords: cancer, communication, phenomenology, symbolic interaction, survivor.

\begin{abstract}
Abstrak: Masyarakat menyangka bahwa kanker adalah penyakit mematikan. Jurang komunikasi antara dokter dan pasien menghasilkan informasi yang tidak lengkap yang diperoleh penderita kanker. Riset ini dilakukan dengan menggunakan metode kualitatif untuk mengeksplorasi makna kanker yang dianut para penyintas kanker yang tergabung di Bandung Cancer Society. Teori yang digunakan adalah fenomenologi dan interaksionisme simbolik. Hasil penelitian atas 10 informan menunjukkan bahwa bagi mereka kanker adalah penyakit yang menakutkan; tidak dapat diobati dan tanpa harapan melanjutkan hidup; disebabkan oleh gaya hidup tidak sehat; namun kanker dapat meningkatkan ibadah mereka. Semua informan sebagai penyintas kanker berupaya untuk menjadi penyintas dengan mematuhi nasihat dokter. Hasil lainnya dari penelitian ini adalah bahwa komunikasi yang terjadi antara penyintas kanker dan orang lain yang menderita kanker di Bandung Cancer Society mampu mengubah pandangan para informan tentang kanker, memotivasi dan meningkatkan semangat hidup mereka.
\end{abstract}

Kata kunci: kanker, komunikasi, fenomenologi, interaksi simbolik, penyintas.

DOI: https://doi.org/10.29313/mediator.v12i2.5219 


\section{INTRODUCTION}

The number of people with cancer has increased from year to year. Cancer has even become one of the leading causes of death or number one killer. The most recent data shows that in 2018 there were 18.1 million new cases of cancer with the death rate being 9.6 millions all over the world. More specifically, the ratio of cancer in Indonesia is $136.2 / 100,000$, occupying the $8^{\text {th }}$ rank in Southeast Asia and the $23^{\text {rd }}$ in Asia. It is noted that breast cancer is the type of cancer with the highest percentage of new cases to women which is 42.1 per 100,000 , with the average number of deaths being 17 per 100,000 (Ministry of Health, 2019). It is assumed that one of the problems related to the increasing number of cancer cases is a communication gap between people with the disease and the doctors who treat it, as implied by Mulyana (2008) in his inaugural address as a professor who stated that there are many doctors communicating poorly to their patients.

Another problem faced by cancer sufferers is the lack of intense communication services performed by doctors with the patients of cancer due to time limitations affecting doctors when performing medical services. Lack of time is one of the four communication barriers between medical practitioners and patients as found by Hardee and Platt (2010). It is even more so in Indonesia where the ratio between doctors and patients is worse than in most Western countries. Therefore, the sufferers do not really analyze the matters related to the disease. It is frequently found that the people are investigating the information from parties who lack competence in dealing with the problems of the disease, so that there are many people with cancer who obtain information from parties who do not necessarily master the problems completely.

Deaths always haunt the patients who consult with the doctor when there is a state of disorder that occurs in the body. After the doctor has finished doing the examination and making observations on a patient, he very carefully conveys the results of his observations to the patients that have been exposed to cancer. Then the reaction from the patient when the doctor says that the patient has cancer is stunned, complaining, calm and listening, shocked and hysterical, or he or she can even faint. The various kinds of reactions of people with cancer are phenomena that display expressions of how people define cancer.

Therefore, the meaning gained by a person will not be the same even if the object (in this case, cancer) faced is the same. Each person will produce a diversity of meanings according to his own way of thinking, as assumed by the theory of symbolic interaction (Blumer, 1969). The meaning expressed by a person will depend also on the way he communicates. The communication factor that is an integral part of every human life is very important in fostering relationships in groups and interpersonal relationships in various areas of life. Communication process in the field of health is generally done by patients with health services or with other parties who are considered able to participate in solving the disease problem faced.

The problems faced by cancer sufferers is the lack of intense communication services conducted by doctors to the patients, due to the time constraints of the doctors when performing medical services. Many people with diseases express their disappointment. For example, when making medical efforts through medical services like hospitals, they often experience dissatisfaction in their communication with the medical officers, especially the doctors. This occurs due to the lack of optimum opportunities provided by doctors to 
be able to communicate in an intense and open way because of limited time available to doctors, but this limitation is very understandable considering that there are a lot of patients that have to be served. Dialogic communication factors are considered important because they can reduce the burden suffered by patients, but this is not understood by healthcare providers. In such cases, it is possible to support patient treatment efforts, if healthcare providers can respond interactively.This lack of interaction causes cancer sufferers to not investigate certain or particular things related to the disease. It is often found that people are obtaining information from parties who lack competence in dealing with the problems of the disease, or that many cancer sufferers gain information from parties who do not exactly master the whole problem.

Assuredly, good communication intensity between medical officers and their patients will greatly assist patients to cure their illnesses. Susanne Dida (2011) points out that, the communication ability of the healthcare personnel can have an effect on a patient's healing. Healthcare officers with good knowledge and communication skills will have an influence that is also good for the patient's perception of service, trust and recovery stages. Dida adds that transformation of relationships between healthcare workers and patients is now on the way to being a partnership. Healthcare services require partners who are commensurate, committed and aware of their respective roles. Healthcare Communication can bridge the relationship between healthcare personnel and the patients to achieve optimum results.

Good communication between doctors and patients has great potential in helping patients to maintain emotion control, improve understanding of medical information, perceptions and expectations, and build full trust in the doctors who can then handle it because the patients will obey the advice or suggestions. Due to the communication gap, the sufferers do not find out more deeply about the deseases, and many people amongst them look for the information from parties who are less competent in dealing with the disease problems such as through some alternative treatment paths.

The phenomenon about the meaning of cancer to the survivors in Bandung Cancer Society is interesting to study, because they not only can empower themselves but can also socially interact with each other through interpersonal communication. According to Tubbs and Moss (2008), interpersonal communication is a process of communication that is characterized by the realization of mutual understanding, pleasure, mutual influence, good social relations, and the real action environment that provides feedback as well. Departing from that point, the researchers became interested to examine the meaning of cancer for cancer survivors in Bandung Cancer Society.

In Indonesia research into health communication based on the phenomenological perspective is scarce. It incorporates, among others, studies carried out by: Teja (2006) who examined patients' social construction of leprosy at the Sinatala Hospital in Tangerang; Hadisiwi (2011) who investigated the meaning of filariasis as constructed by those who suffered from such illness in Bandung Regency; Hafiar (2012) who explored the subjective experiences of disabled athletes in Bandung; Mulyana and Kadri (2016) who investigated olygodactyly sufferers' communication experiences in the Village of Ulutaue, South Sulawesi; and Mulyana and Kadri (2019) who explored the identity transformation of blind people with blindness in adulthood in the Wyata Guna 
Rehabilitation Center in Bandung.

\section{Theoretical Basis}

In this study, the researchers consider that human existence is inseparable from its subjectivity and the role of society as a place to socialize, where people meet and interact through communication. The theories that will be discussed in this study consider human activities important. In this regard, the researchers use phenomenology that becomes the basis for understanding the phenomenon that occurs among the sufferers, the theory of symbolic interaction as an effort to seek perception about the phenomenon that occurs among the sufferers and deepening of the subjective condition of the sufferers.

Behavior that appears in people with cancer is an interesting phenomenon. Conditions that occur among the sufferers generally shackle themselves from feelings that are subjective and construct them as human beings who are out of the social life. The low self-esteem accompanied by a pessimistic attitude toward their future accumulates into human beings who behave differently from others. They sometimes feel difficulty in communicating for fear of getting a question about their illness that eventually elicits a sense of compassion from their interlocutors. To understand the behavior, phenomenology is deemed a suitable theory.

According to Natanson (in Mulyana, 2018:95), phenomenology is defined as a generic term to refer to all social views which consider human consciousness and its subjective meaning as the focus for understanding social action. While Schutz (in Creswell, 1998:53) explains that phenomenology examines how members of a society describe the everyday world, especially how the individual with his consciousness builds meaning from the interaction that results from interaction with other individuals. Phenomenological analysis can construct the worlds of human life in their own forms. Therefore, the approach of Schutz's phenomenology is more specialized in how the formation of the human world through the consciousness of intersubjectivity.

A variant of phenomenology is symbolic interactionism. According to Blumer's view (in Mulyana, 2018:108), the social process in the life of the group creates and enforces rules, therefore it is not the rules that create and uphold the life of the group. In this context, meaning is constructed in the process of interaction, and the process is not a neutral medium that allows social forces to play their role, but it is the substance of social organization and social forces, so obviously society is a process of symbolic interaction.

Symbolic interactionist perspective can simply be based on three basic premises. First, the individual responds to a symbolic situation. They respond to the environment, including physical objects and social objects (human behavior) based on the meanings conceived by those components of the environment. For them individuals are considered active in determining their own environment. Second, the meaning is the product of social interaction, so that the meaning is not attached to the object, but is negotiated by the use of language. The meanings interpreted by the individuals may change from time to time, in line with the changing circumstances found in social interaction. Changes in interpretation are possible because the individuals can perform a mental process, i.e. communicating with themselves (Mulyana, 2018:109-110).

Following such theoretical tenets, researchers would like to explore the cancer survivors' subjective experiences, or simply put, how they define cancer. As Marks et al. (2000:6) point out, 
"People's accounts of health and illness are interesting and illuminating topics of study in their own right." Thus, if cancer is socially constructed as a disease that cannot be cured, then at this time it becomes negative in meaning, so the meaning of cancer that cannot be cured will be an objective reality for people with cancer. However, the meaning can change following the social dynamics that occur in the society.

\section{RESEARCH METHOD}

This research is part of a larger research project that lasted four years, from 2014 to 2018. The study examines the personal consciousness based on experience that has been owned, its focus being the meaning of cancer according the subjects of the study.

To achieve the objective of this research, the researchers have interviewed 10 cancer survivors who were members of the Bandung Cancer Society, and one medical specialist. As Duke suggests, in a phenomenological study, three to 10 subjects is deemed sufficient (Creswell, 2013). For the sake of confidentiality, the researchers have used initials to represent the actual names of the informants. The age of the informants ranges from 28 to 67. They consist of eight women and two men. Each informant was interviewed between twice and four times, each lasting between one and two hours.

Since the core of phenomenology is the personal experience or consciousness from the perspective of the subjects, the researchers have carried out interviews and observations followed by data analysis in order to obtain conclusions. The data gained on the informants' subjective experience and the meaning of cancer were then categorized into patterns experience and/or meaning developed by researchers, thus the model of the research being inductive as commonly done in phenomenology.

\section{RESULTS AND DISCUSSION}

From the results of the research in Bandung Cancer Society based on age category it is obvious that cancer is mostly suffered by people with the age group from 51 years to 60 years. Cancer emerges when there is a trigger, such as when a person's condition is declining. The age of 51 years - 60 years is a very vulnerable age in terms of stamina, especially if one's lifestyle is not healthy, like not maintaining one's body condition by getting used to exercise, sleeping irregularly, and eating without good control, so that it is very easy for cancer to attack.

Based on the results of the research, females suffer most from cancer. This is in accordance with the statement of the Chairman of the Indonesian Oncology Society, Dr. Drajat Suardi, Sp.B (K) Onk, based on our interview with him in March 2015 , that this is closely related to risk factors. "The risk factors include faster menstruation, slower menopause and smaller numbers of children. In big cities, women want slower menopause because they always want to look beautiful and to have fewer children, so the exposure to estrogen hormones becomes longer. Longer estrogen eventually leads to a higher risk of breast cancer," said Dr. Drajat Suardi, Sp.B (K) Onk. However, these risk factors do not just necessarily become cancer. Dr. Drajat says there are internal and external factors that can trigger cancer cells. "Internal factors are due to genetic abnormalities. There is a type of gene that is called oncogene that accelerates the malignancy of tumor cells, and suppresses genes that slow it down. When a virus infection occurs, it can eventually result in oncogenes becoming more rapid or suppressor gene failing to function."

In addition to internal factors, there are external factors, i.e. 1) biological factors, such as bacteria and viruses that 
can transform mutated cells into further mutations, 2) chemical factors, such as food and hormonal dyes, 3) physical factors, such as those originating from internal factors and then coupled with burns that cause keloid and often rubbed, which eventually leads to skin cancer. "There are also environmental factors. In Japan, many people get stomach cancer probably because of the food. They like to eat with a lot of vinegar. While in India they like to chew areca nuts that contain certain substances that can trigger cancer," said Dr. Drajat when the researchers interviewed him.

\section{The Meaning of Cancer According to Cancer Survivors}

From the results of interviews with cancer survivors, as research informants, it was revealed that the meaning of cancer by cancer survivors in Bandung Cancer Society is as follows:

\section{Cancer Is Frightening}

Cancer is characterized by a physical change in the body of a person with cancer, including a sudden lump in the body that raises feelings and questions about the change. Someone who suddenly felt the existence of abnormalities in the body such as a lump would feel worried and anxious. Moreover, the existence of runours that where a lump suddenly appears in the body, one must be wary of a tumor because the tumor can be benign or even malign. All informants say that cancer is considered frightening and very dangerous because of its ability to spread far to all of the body parts and then form new cancers, and it is distressing and scaring just imagining that the disease is known as the silent killer and that there is no cure. It is, therefore, very reasonable for the society to make the stigma that cancer is frightening.

One cancer survivor, ADP, for example, said:
Cancer is a scourge for me, because cancer cells split very quickly and we do not know when they split, so it is a very horrible disease. When doctors diagnosed that I had breast cancer, the world felt like it was crumbling, and at that time I thought that my life will not be long, as if death will come soon.

Another cancer survivor, ST, said:

I was so scared after knowing I had cancer and I had heard a lot that cancer has no cure, and that the medical treatment is very painful, not to mention its side effects, so that, in the end, I decided not to see the doctor straight away. I was then asking about it to others who did not necessarily master the problems or did not have competence with cancer, even though I realized that their views could be misleading. Then a friend suggested to me to be treated herbally, and I followed the advice by visiting herbal medicine institutions in different places, but it was never healed, and the lump was even getting bigger and frightening.

Finally ST went to the oncology doctor and conducted a series of tests, and the result was that she has to undergo chemotherapy. At that time she imagined how painful it would be to undergo chemotherapy with various side effects, like hair falling out and becoming bald, dry skin, black nails and how her weight would drop dramatically. The image of chemotherapy was so scary that she had hesitated to follow the doctor's advice. Luckily she was able to communicate with other cancer survivors in Bandung Cancer Society who provided enlightenment from their various experiences so as not hesitate to follow the doctor's advice.

Another informant SS said that she lost consciousness and fainted after hearing the doctor's verdict that she had bowel cancer. She imagined that cancer is so frightening because suddenly it could 
take her life, and was thinking about her children who would loose their mother. She did not feel ready yet to leave her children who still need their mother's presence.

Then there is YS who said,

Who is not afraid when we get cancer? The fear is very stressful and dispassionate, and I did not want to do any activities. As soon as the doctor gave his prognosis, I always lay down and confined myself in the bedroom while imagining the next fate.

\section{Cancer Cannot Be Cured}

The issue developed in the society is that cancer cannot be cured. This is reinforced by the number of people who have died of cancer. Based on the data of death cases of cancer disclosed by WHO, it is predicted that in 2030 cancer cases in the world will increase to $60 \%$. This figure is clearly not just appearing, but it refers to a number of facts increasing about the cancer cases from year to year around the world.

Based on cancer statistics published by the National Institutes of Health, in 2010 the number of new cancer cases reached 1.52 million. In 2011, new cancer cases reached 1.59 million. This number increased again in 2012 to reach 1.63 million. Based on data in 2015 , the new world cancer status reached number 1.68 million. From this data alone, it can be concluded that from year to year there is still an increasing number of people with cancer.

All informants initially suspected that cancer could not be healed as revealed by an informant ADP. When she was declared as a cancer sufferer, she felt hopeless because in her mind it was implanted that the disease cannot be cured. ADP said,

The world felt like it was crumbling and I despaired. The doctor suggested radical surgery to maxectomy (removal of the breast), and I immediately said $O K$ and instantly surrendered to what the doctor said. I did not have time to browse the internet or ask other people, so I had the operation immediately.

Another informant ST experienced the same situation,

I could not accept the fact because I was certain that cancer cannot be healed. Initially I did not know what to do, and something strange went on and on in my mind.

A different reaction happened to HMV. She said,

Although I thought that cancer cannot be healed, I tried to get up and motivate myself while praying. In order to be able to survive I promised to God that if this cancer can be cured after going through various treatments I would devote myself to fellow sufferers of cancer as a motivator and give spirit to fight cancer.

While the issue that it is a fact that cancer cannot be cured can be weakened by the presence of a number of cases of people, as expressed by Dr. Andhika who suggests that what is needed is early detection in cancer patients. The earlier the cancer is diagnosed and treated, the more likely it is that it can be healed. However, he does not deny that there are some types of cancers whose symptoms are initially very difficult to recognize and hard to heal and lead to death.

\section{Cancer Is Caused by Unhealthy Lifestyle}

From the research findings conducted by the researchers, according to most informants cancer is caused by unhealthy lifestyles, consuming lots of fast food or eating good tasting food without regarding the nutrient values 
and not doing any sports activities. The informant ADP said,

We got cancer because we had an unhealthy lifestyle, such as consuming food provided by fast food restaurants, eating foods with high levels of fat, drinking alcohol, not exercising regularly, being squeezed by the burden of life and lack of sleep.

While the informant SS said: "I got cancer because of a bad eating habit or insufficient nutritional consumption." In a similar way, HMV assumes that cancer appears due to unhealthy lifestyle. He says, "Cancer comes due to improper diet, stress and poor attention to healthy lifestyles." The youngest informant LP revealed that an unhealthy lifestyle is very influential on cancer outbreaks. "I admit that I have been neglecting proper food intake, eating only when very hungry and wanting it, practicing bad diet and never exercising at all."

What is revealed by the informants ADP, SS, HMV and LP is in accordance with Dr. Rachel Thompson's statement from the World Cancer Research Fund which stated that the report reinforces evidence of the correlation between cancer and lifestyle. Almost half of the cancer cases diagnosed annually in the UK are caused by lifestyle, such as smoking, drinking alcohol, and unhealthy eating patterns. Cigarettes are the biggest cause, about $23 \%$, for cancer among men, while for women the figure is $15.6 \%$, according to a report compiled by the British Cancer Research Institute. Diet that is not healthy, such as rarely consuming fresh vegetables or fruit, becomes the second biggest cause of cancer among men. For women the second largest cause is overweight.

\section{Cancer Increases Acts of Worship}

For those who have a sense of piety towards Allah SWT they believe that every disease will be balanced with the supply of antidote. It is in accordance with the teachings of Islam, the Prophet Muhammad SAW said: "Allah Subhanahu Wata'ala has lowered (sent down) the disease together with the medicine and provided the medicine for every disease, then seek treatment, and do not seek for the treatment with something forbidden" (narrated by Abu Daud). The other hadits also says: "Repent, O servants of God, for Allah does not inflict a sickness unless $\mathrm{He}$ also makes the cure for them, except for one disease, that is death." (narrated by Bukhari). Why does Allah always give us illness, and we become sick? Without being realized, the fact is that all humans consume food that belongs to God and humans enjoy what God gives them, but many people often neglect and do not feel grateful for what God has given to them.

For Muslims, belief has developed that when God gives people illness, and they feel pain, they must accept it as an exercise in order to be patient, be aware of the actions in their past, be closer to the Creator, to ask for forgiveness and to reduce the sins that have been done, educate themselves to become pious and to believe that disease is the grace of Allah.

The results state that most informants convey such an opinion. An infomant DEN, for example, says cancer is inflicted as a warning from Allah SWT about the coming of death, so the presence of cancer on earth is a gift of God that must be accepted naturally. The diagnosis of his cancer hit him on his birthday. DEN explained that it was quite tragic at that time and in the heart he said, "O Allah this is a destiny. Perhaps God signaled that I should reshape my acts of worship."

Similarly, an informant GNS said: "It is the will of God, but there must be a cure and this is the sign that I must always remember Allah with a more diligent and better way of worshiping." 


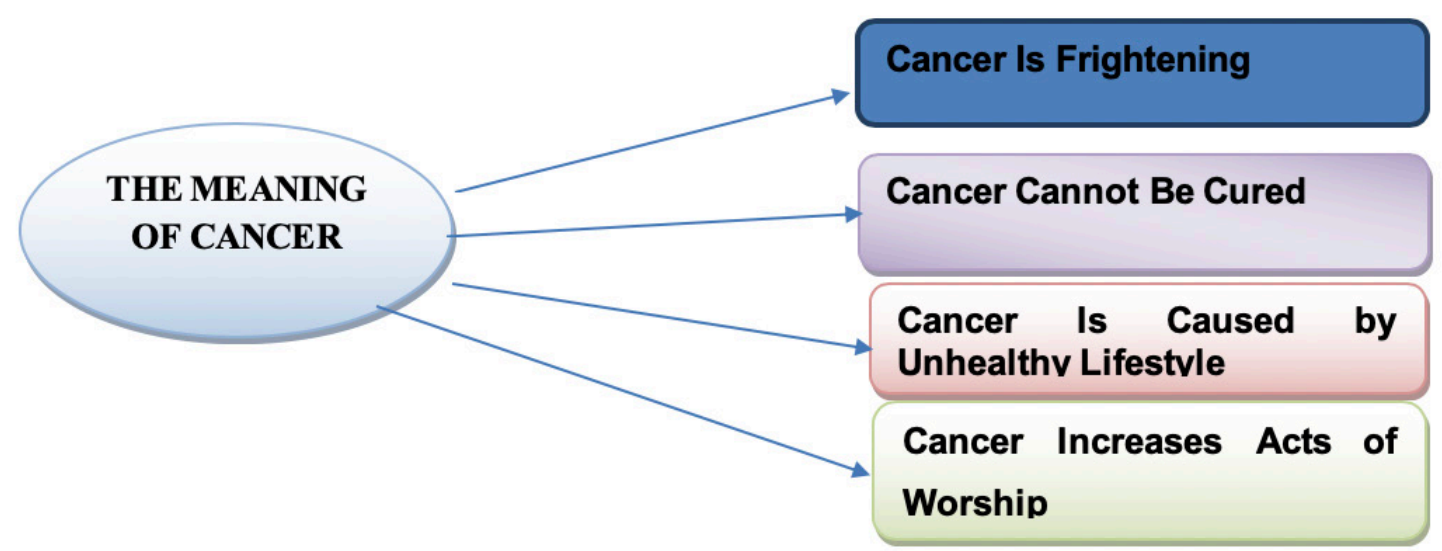

FIGURE 1. Model of the Meaning of Cancer according to Cancer Survivors

While a survivor RH, when facing her disease, always prayed to Allah SWT. She believes that every single thing that happens to mankind is a form of destiny from Allah SWT, so that in order to survive they must accept it. RH said,

We have to believe in Allah SWT, go through the treatment with patience and and sincerity. I honestly feel grateful to Allah SWT for giving me the second chance to live this life and I hope I can be useful for my family and the society.

The informant LP feels confident that the diseases that affect human beings are the will of Allah SWT. He said, "Allah is the Almighty, and he gives me strength. When I was on my own, I realized that when Allah wants us to die, then we cannot refuse it. It is not about cancer or other diseases." Therefore, LP returns her fate to the Supreme Creator. "Cancer can be cured and I am sure there is nothing impossible in the hands of God. In consequence, I surrender and worship God more than ever," he said.

\section{CONCLUSIONS}

This study has shown the usefulness of the phenomenological perspective and the theory of symbolic interaction in unraveling the symbolic reality of cancer. It is clear from the previous results of study that cancer is a deadly disease, not only based on the real data or statistics, but also in the perception of the subjects of this study.

More specifically, based on the whole discussion, it can be concluded that: First, cancer is defined by the research informants as a very frightening disease; that cancer is very difficult to be cured; it causes no hope among its sufferers to survive due to unhealthy lifestyles and can only be dealt with various healing efforts made by medical specialists.

Second, based on their experience, the cancer survivors interpreted that cancer is a disease that can be resisted so that life expectancy can be maintained throughout the medical treatment and the instilled confidence in Allah SWT to be able to heal it.

Third, the communication between cancer survivors with other fellow sufferers can change the view of cancer and provide motivation and encouragement to try to maintain life expectancy.

\section{REFERENCES}

Blumer, H. (1969). Symbolic Interactionism: Perspective and Method. Englewood Cliffs, NJ: Prentice-Hall.

Creswell, J.W. (1998, 2013). Qualitative Inquiry and Research Design: Choosing among Five Approaches. Third 
Edition. Los Angeles: Sage.

Hadisiwi, P. (2011). Konstruksi Makna Penyandang Filariasis: Studi Fenomenologi tentang Konstruksi Makna Penyandang Filariasis dalam Komunikasi Risiko Kesehatan di Kabupaten Bandung. Unpublished Doctoral Dissertation, Postgraduate Program, Padjadjaran University.

Hafiar, H. (2012). Cacat dan Prestasi Melalui Pengalaman Komunikasi Atlet Penyandang Cacat: Studi Fenomenologi Mengenai Konstruksi Makna Kecacatan dan Status sebagai Atlet Berprestasi Melalui Pengalaman Komunikasi Atlet Penyandang $\mathrm{Ca}-$ cat Berprestasi di Bandung. Unpublished Doctoral Dissertation, Postgraduate Program, Padjadjaran University.

Hardee, J. T., \& Platt, F. W. (2010). Exploring and Overcoming Barriers to cCinical Emphathic Communication. Journal of Communication in Health, 17-21.

Marks, D.F., Murray, M., Evans, B., \& Willig, C. (2000). Health Psychology: Theory, Research and Practice. London: Sage.

Mulyana, D. (2008). Membangun Komunikasi Kesehatan di Indonesia. Pidato Pengukuhan Jabatan Guru Besar dalam Ilmu Komunikasi pada Fakultas Ilmu Komunikasi Unpad.

Mulyana, D. (2018). Metodologi Penelitian Kualitatif: Paradigma Baru Ilmu Komunikasi dan Ilmu Sosial Lainnya. Ninth (Revised) Edition. Bandung: P.T. Remaja Rosdakarya.

Mulyana, D. \& Sulaeman (2016). People with Lobster - Claw Syndrome: A Study of Olygodactily Sufferers and Their Communication Experiences in the
Village of Ulutaue, South Sulawesi, Indonesia. Mediterranean Journal of Social Sciences, 7 (1), 136-144.

Mulyana, D. \& Kadri. (2019). Identity Transformation of Blind People with Blindness in Adulthood. Mimbar, 35 (1), 235-244.

Teja, M. (2006). Stigma dan Komunikasi: Kehidupan Masyarakat Sembuh Kusta: Studi Kasus di Komplek Rumah Sakit Kusta Sinatala, Tangerang, Banten. Unpublished Master's Thesis Padjadjaran University.

Tubb, S \& Moss, S. (2008). Human Communication: Prinsip-Prinsip Dasar. Editor Deddy Mulyana. Bandung: P.T. Remaja Rosdakarya.

Dida, S. (2011). Kemampuan Komunikasi Tenaga Kesehatan Pengaruhi Kesembuhan Pasien http://news.unpad. ac.id/?p=43479

Hadisiwi, P. (2011) http://news.unpad. ac.id/?p=43479Kanker disebabkan oleh $40 \%$ Gaya Hidup-BBC Indonesia,.....www.bbc.com/indonesia/majalah/2011/12/111207_kanker, diunduh 13 Oktober 2017 jam 00.36 WIB

Situasi Penyakit Kanker, Infodatin Pusat Data dan Informasi Kementerian Kesehatan RI http://www.depkes. go.id/resources/download/pusdatin/ infodatin/infodatin-kanker.pdf diunduh 7 Oktober 2017 jam 21.14 WIB

Tiga Alasan Kenapa Kanker Di Dunia Semakin Meningkat, Deherba.Com, ...https://www.deherba.com/3-alasan-kenapa-kanker-di-dunia-semakin-meningkat.htmldiunduh 12 Oktober 2017 jam 22.00 WIB

Yayasan Kanker Indonesia, Apakah kanker itu? http :yayasankankerindonesia. org/tentang-kanker/ 